\title{
Other Management Occupations
}

National Cancer Institute

\section{Source}

National Cancer Institute. Other Management Occupations. NCI Thesaurus. Code C122549.

Management occupations not specifically identified elsewhere. 